\title{
VERBAL INTERACTION BETWEEN TEACHER AND STUDENTS IN ENGLISH CLASSROOM IN SMP SWASTA PAHLAWAN NASIONAL MEDAN
}

\section{AN ARTICLE}

Submitted in Partial Fulfillment of the Requirements for the Degree of Sarjana Pendidikan

By:

\section{OKTAVIANI TAMPUBOLON}

Registration Number: 2113321036

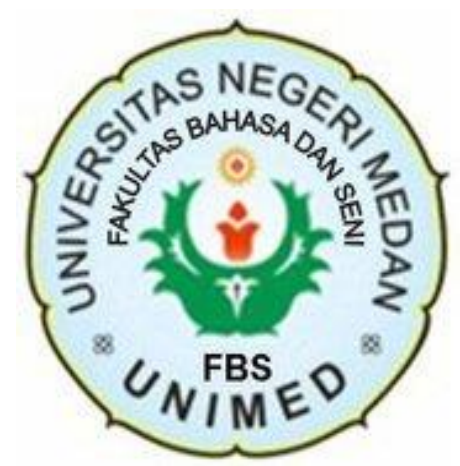

ENGLISH AND LITERATURE DEPARTMENT

FACULTY OF LANGUAGES AND ARTS

STATE UNIVERSITY OF MEDAN

2018 


\section{ARTIKEL \\ VERBAL INTERACTION BETWEEN TEACHER AND STUDENTS IN ENGLISH CLASSROOM IN SMP SWASTA \\ PAHLAWAN NASIONAL MEDAN}

Disusun dan Diajukan oleh:

Oktaviani Tampubolon

NIM. 2113321036

Telah diverifikasi dan dinyatakan memenuhi syarat

Untuk diunggah pada jurnal online

Medan, $\quad$ Agustus 2018

Menyetujui

Dosen Pembimbing Skripsi I

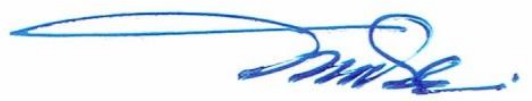

Prof. Dr. Zainuddin, DIP, TEFL., M.Hum. NIP. 195201021980121001
Dosen Pembimbing Skripsi II

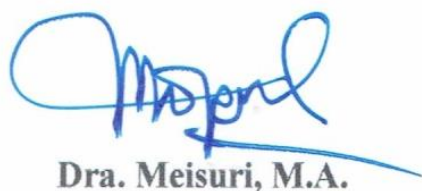

NIP. 196105231987032006

Nora Ronita Dewi, S.Pd., S.S., M.Hum.

NIP. 198005522008122003 


\title{
VERBAL INTERACTION BETWEEN TEACHER AND STUDENTS IN ENGLISH CLASSROOM IN SMP SWASTA PAHLAWAN NASIONAL MEDAN
}

\author{
*Oktaviani Tampubolon \\ ** Prof. Dr. Zainuddin, DIP. TEFL., M.Hum \\ **Dra. Meisuri, M.A.,
}

Tampubolon, Oktaviani. 2113321036. Verbal Interaction between Teacher and Students in English Classroom in SMP Swasta Pahwlawan Medan. A Thesis. Engilsh and Literature Department, Faculty of Language and Arts. State University of Medan. 2018

This study deals with verbal interaction between teacher and students at SMP Swasta Pahlawan Nasional. The objectives of this study were to find out the category of verbal interaction between the teacher and the students in the classroom, and the dominant category of verbal interaction in the classroom between teacher and students. Data of the research was taken from 28 students of eight grades which took an English class involved one English teacher who taught in the class. The data in this research collected by using interview and videotaping. The result of the study showed that both the teachers and the students were aware and understood that interaction was important in English learning. They also understood that to be able to interact well, they needed to practice. But, the understanding was not supported by what they did in classroom. The teacher did not give much interactive activity in class. It seemed that the teachers did not believe in the students' competence. The students were not active in practicing their English by asking questions or expressing their idea or opinion, and the most dominant interaction between teacher and students were direct teacher interaction.

Keywords : verbal interaction, teacher and students

*Graduate Status

** Lecturer Status 


\section{INTRODUCTION}

\section{Background of the Study}

English is an international language and is the most popular language used by almost all the people in the world to communicate with others in so many fields, for example in education, correspondence, business, and the internet. So, English becomes one of the essential languages that have to be studied to broader mind and knowledge about anything. English has been taught in Indonesia and takes a role as a foreign language.

Teaching is the activities of showing, guiding and facilitating the students, enabling the students to do something and providing new knowledge for the students (Brown, 2000). Teaching activity requires a teacher and students and also a classroom, a place for the students to absorb the knowledge. Teacher is regarded as the source of knowledge for the students. One of the roles of teachers is to facilitate the communication process between all participants in the classroom, and between these participants and the various activities in the class (Richards and Lockhard, 1996). In teaching and learning process in classroom, the teachers as a source of knowledge usually get involved with the students by having a purposeful interaction between the teacher and the students. In teaching learning activity, so many interactions happen in the classroom. All of those activities are happened trough verbal and gestural. Verbal means interact or communicate through spoken and written by using language and gestural by using movement of lips, or the wink of an eye or the wave of hands.

In order to accomplish a certain purpose during teaching and learning process, the teacher and students must create a communicative interaction in the classroom. Creating a communicative interaction between the teacher and the students is really important for students' development. In the classroom, students should learn to interact, listen to others, and talk with others. In the classroom interaction, teachers usually dominate the interaction. They use verbal interaction to explain the material, to ask the students and the students also use verbal communication to interact with other students.

Verbal interaction is greatly helps the students to learn English. They can use all they have learned in real-life communication by practicing their English ability 
trough verbal interaction. In this way students get the experience of using the language. This kind of experience is helpful in promoting language development. Harmer (1998) states students are the people who need practice, not the teacher. Thus, the teacher should maximize the student talking time and minimizes teacher talking time. A good teacher will be able to control their talking time in classroom interaction. Ellis (1985) states that if students obtained more practice in the target language, they would be more motivated to engage in further communication when they had the opportunities to speak. Rivers (1987) thinks verbal interaction is important because students can increase their language store as they listen to others including both the teacher talk and their fellow students in in discussions or dialogue.

Through verbal interaction, students can demonstrate their proficiency and practice their target language. Moreover, Malamah (1987) recommends that interaction will help students to attain better learning and give opportunities to train their competences. They get their competences by listening to the teacher and the students, and communicating with the teacher and the student. To have interrelated interaction, the teacher is not only facilitating the students to learn but also stimulating students to get involved in participation. The researcher concludes that increasing students English ability as the responsibility of the teachers in the classroom is through verbal interaction, because the teachers will know what the students known and unknown by stating it orally.

Verbal interaction is regarded to be essential to language learning. Despite that importance of verbal interaction, it's still a problem in the classroom. In fact, the students' talk is less than the teacher, means that the teachers more active than the students. According to the survey which is conducted by Suherdi (2009), from the sixty-two SLTP and SMU teachers in West Java, Banten, and DKI revealed that most of the students participation was still low. Suherdi explained that it is because students tend to have low confidence and lack of independence in organizing their learning. It reveals the percentage of teacher talk is more than $55 \%$. It can make students have less opportunity to speak and it is not good for improving students' ability to talk in the target language. The teachers are talking too much without allowing the students to talk. 
Murtiningrum (2009), Classroom Interaction in English Learning. The teacher interacted with individual students by accepting feeling, praising or encouraging, accepting or using ideas of the student, asking questions, lecturing, giving directions, reminding noisy students, and helping the student's work.

To acknowledge what actually happens in classrooms, based on the FIACS (Flander, 1970), there are three categories in the classroom interaction; they are teacher talk, students talk, and no/all talk/silence and how the classroom interaction goes on, especially the verbal interaction should get a high attention. Thus, this study aims to investigate verbal interaction of the teacher and the students in a junior high school and what kinds of verbal interaction which is found in the classroom according to FIACS. Finding those matters, it became more challenging to find what really happened classroom interaction, especially in verbal interaction. This picture will help teachers reflect what they usually perform in the classroom and in this way they may find out some problems in their teaching.

\section{REVIEW OF LITERATURE}

\section{Classroom Interaction}

Interaction is synonymous with the learning process itself (Allwright and Bailey, 2008). Interaction develops the learner's ability of a language. By interaction, a language learner can get more opportunity to use language successfully. Interaction also measures the learners' progress.

Interaction is the hearth of communication (Brown, 2001:165). It is in the interaction what communication all about is found. It can be in the forms of sending messages, receiving them, interpreting them, or negotiating meanings. Communication plays a central role in all classroom activities. Classroom communication is similar to other communication forms. But, the classroom communication differs as a function of unique purposes, environment, and participation forms. The classroom communication involves some components. They are: the originator, encoding process, transmission, message, channels, communication climate, interference, reception, decoding, responder, and feedback (Barker, 1982: 14). 


\section{Classroom Verbal Interaction}

Interaction is the collaborative exchange of thoughts, feelings, or ideas between two or more people, resulting in a reciprocal effect on each other (Brown, 2001: 165). Interaction occurs when there is understanding between two or more people, then giving responds. This is the most important aspect that must be achieved by the learners when studying a language, because interaction is considered as the way to get information. Verbal interaction is the most important thing for the learners to get and to learn language in order to communicate in the target language. Classroom is the place for the learners to enrich and absorb their knowledge about the target language. It can be concluded that the classroom verbal interaction is an interaction among the teacher and students in the classroom. Brown (2001: 165) defines interaction as the collaborative exchange of thoughts, feelings, or ideas between two or more people, resulting in a reciprocal effect on each other. It is also supported by Lynch (1999), classroom verbal interaction is a verbal exchanges produced by both teacher-students and student-student interaction in classroom (Lynch,1999).Successful verbal interactions will occur when both the teacher and students could completely understand what each other means. It happens verbally among the teacher and students during the teaching learning activity. It becomes one of the important things in learning a new language as well as the first language.

\section{Teacher's Role in Teaching Learning Process}

Cameron (2001) has already given the general description about teaching. She emphasizes that teaching is a process to construct opportunities for learning and to help learners take advantages of them.

It can be drawn that in a teaching learning process, the teachers should be able to help the students in constructing understanding towards the lesson.

\section{Flanders Interaction Analysis Categories System}

Flanders (1970) originally developed a research tool, namely Flanders Interaction Analysis (FIA). FIA is a system of classroom interaction analysis and became widely used coding system to analyze and improve teaching skills. Flanders developed a system of interaction analysis to study what is happening in a classroom when a teacher teaches. Flanders coding system consists of ten categories of communication 
which are said to be inclusive of all communication possibilities. Seven categories are used to categorize various aspects of teacher talk and two are used to categorize student talk. The last category is used when there is silence or confusion in the class. The figure below shows the Flanders categories in classroom interaction.

Table 2.1 Flanders Interaction Analysis Categories System

\begin{tabular}{|c|c|c|}
\hline \multirow{4}{*}{$\begin{array}{l}\text { Indirect } \\
\text { Teacher } \\
\text { Talk }\end{array}$} & 1 & $\begin{array}{l}\text { Accepts feeling } \\
\text { Acknowledge student-expressed emotions (feelings) in a } \\
\text { nonthreatening manner }\end{array}$ \\
\hline & 2 & $\begin{array}{l}\text { Praises or encourages } \\
\text { Provides positive reinforcement of student contributions }\end{array}$ \\
\hline & 3 & $\begin{array}{l}\text { Accepts or uses ideas of students } \\
\text { Clarifies, develops, or refers to student contribution, often } \\
\text { non evaluatively }\end{array}$ \\
\hline & 4 & $\begin{array}{l}\text { Asks questions } \\
\text { Solicits information or opinion (non rhetorically) }\end{array}$ \\
\hline \multirow{3}{*}{$\begin{array}{l}\text { Direct } \\
\text { Teacher } \\
\text { Talk }\end{array}$} & 5 & $\begin{array}{l}\text { Lecturers } \\
\text { Presents information, opinion, or orientation; perhaps } \\
\text { includes rhetorical questions }\end{array}$ \\
\hline & 6 & $\begin{array}{l}\text { Gives directions } \\
\text { Supplies direction or suggestion with which a student is } \\
\text { expected to comply }\end{array}$ \\
\hline & 7 & $\begin{array}{l}\text { Criticizes or justifies authority } \\
\text { Offers negative evaluation of student contribution or places } \\
\text { emphasis on teacher's authoritative position. }\end{array}$ \\
\hline \multirow{3}{*}{$\begin{array}{l}\text { Student } \\
\text { Talk }\end{array}$} & 8 & $\begin{array}{l}\text { Student talk - response } \\
\text { Gives a response to the teacher's question, usually a } \\
\text { predictable answer }\end{array}$ \\
\hline & 9 & $\begin{array}{l}\text { Student - initiation } \\
\text { Initiates a response that is unpredictable or creative in } \\
\text { content }\end{array}$ \\
\hline & 10 & $\begin{array}{l}\text { Silence or confusion } \\
\text { Leaves periods of silence or inaudible verbalization lasting } \\
\text { more than } 3 \text { seconds }\end{array}$ \\
\hline
\end{tabular}

\section{RESEARCH METHODOLOGY}

This research was conducted by using descriptive qualitative research. The study focuses on verbal interaction analysis in the VIII grade class of Junior High School at SMP Swasta Pahlawan Nasional. The goals of this study were to get description of how the verbal interaction between teacher and students conducted and what kind of verbal interaction happen in the classroom. Best and Khan (1989) state that qualitative descriptive is a method that describes, records, analyses, and 
interpret conditions that exist in a certain group. Furthermore, descriptive method determines and reports the way things are and the researcher has no control over the variable that will being researched. This method is used since this study is not search for something or makes prediction. It only describes the situations or phenomenon (Creswell, 2009:22). In this design, how the verbal interaction is conducted and what kinds of verbal interactions which is occur in the classroom will be described. The frequency percentage as mean may be used to support the description.

The participants of this study were 40 students of eight grades which took an English class involved one English teacher who teaches in that class.

To describe what the teacher and students' talk in classroom interactions, this study required videotaping as one of the research tools. This study used videotaping to capture natural interaction in detail. Allwright and Bailey (1991) state the appropriate way to gather more complicated enquiries or more details data is audio record or even video record, so that we can get what was said, by whom, in what tone of voice. In addition, Burns (1999) argues that videotaping provides data of the classroom interaction both in verbal and in non-verbal behaviour. Videotaping of the whole processing was made to acquire more complete data about the classroom process.

When interpreting the interaction into the code, sometimes there are some confusion words that difficult to interpret. So, Flanders explained the rule of the categories in order to get the good understanding while conducting the research.

The following procedures of analysis the data were:

1. Segmenting the transcript based on each exchange.

2. Coding and analyzing based on FIAC (Flander's Interaction Analysis Categories).

3. Calculating the number of each type of code, the number of teacher and student talk and type verbal interaction occurred.

4. Calculating the amount of teacher and students talk and analyzing them to seek the balance between teacher and student talk using FIAC (Flander's Interaction Analysis Categories).

5. Analysing the type of verbal interaction used by the teacher based on Flander's Interaction Analysis Categories. 


\section{RESEARCH FINDINGS AND DISCUSSIONS}

Research findings

\section{Classroom and Multimedia Laboratory Setting}

In SMP Swasta Pahlawan, there was no special classroom for English class. The English lesson was done in the regular class. Students were in the same classroom in one day for the theory lesson. The teacher moved from one classroom to another.

There were 28 students in class VIII-A. The time of the English lesson was 90 minutes per meeting. In a week there were two meetings: on Monday and on Wednesday.

The classroom setting was in classical one. All students sat in one direction, face to face with the teacher. Two students had one table.

\section{English Learning in Class VIII SMP Swasta Pahlawan}

English learning in SMP Swasta Pahlawan was done cooperatively with a private English course "HL". This was aimed to help the students increase their English communication skills. Class VIII had two meetings every week: on Mondays (at 12.15-13.45) and on Wednesdays (at 10.15-11.45). On Mondays the students studied in the classroom with the teacher from the school (that was Mrs. Nissa). On Wednesdays, the students studied English with "HL". The "HL" class was in the Multimedia Laboratory. Because the capacity of the Multimedia Laboratory was only for 20 students whether there were 28 students in Class VIII, the students were divided into two groups. One group studied in the Multimedia Laboratory while the other group studied in the classroom. On the next meeting/week, they changed the place.

\section{The Result of the Interview}

Before coming to the discussion about the result of the interview, I would like to describe the participants and the interview process The participants of this research were two English teachers and three students.

I had interview with Mrs. Nissa for 4 times and once with Mr. Kris. The interviews with Mrs. Nissa were done in the teacher room (3 times) and in the library (once). I made an appointment before I met her. The interviews took time for about 15 - 30 minutes. She gave me much information about the English 
learning in her class. She was very cooperative and helpful. The interview with $\mathrm{Mr}$. Kris was done in the Multimedia Laboratory. I also made an appointment before I met him. The interview was done in 30 minutes. The interviews with the two teachers were in Indonesian; but, in some expressions we used English.

The interviews with the students were done 5 times: with Sugi (2 times), Imam (once), and Heru (2 times). It took time for about 30 minutes in each interview. Before interviews, I always asked their teacher's permission because I would take their time. Actually, I wanted to do the interviews when the students were having break. But, they were unwilling because they usually went to the canteen with other friends in that time. The interviews were done individually and outside the classroom. The students were very helpful. They gave me much information and answered my questions clearly. The interviews were done in Indonesian.

The presentation of the observation result is preceded by the description of the observation done in the classroom and the Multimedia Laboratory. bThe observation was done 2 times. I came to Mrs. Nissa's class for 2 times. The frequency of the observation was related to the topic being taught in the class. I followed the class from the beginning until the end of the class. I came to the class as a researcher. I brought a notebook and a little audio-video recorder. In the first coming, the students were quite confused about my coming. Fortunately, Mrs. Nissa explained to them about me and what I would do. She also gave me time to introduce myself to the students. Later, the students were very cooperative. I always sat at the back raw, so I could watch everything. In the first observation, I felt very busy in class. There were so many things to be observed and to be recorded. I had to write so many important points too. I had some points from the interview with Mrs. Nissa in my notes. I would check it with what she did in class. But, it was so complicated. I got stressed and almost frustrated. Later, I realized I would not be able to do, write, and record everything. The observation guide that had been made before helped me to focus to what to be observed.

\section{Discussion}

The following was the discussion about the teacher-student interaction that happened in the English class. The condition of the English class was quite conducive. The students had good attitude to the teacher. They paid attention to the 
teacher when the teacher explained the material. They did the activity asked by the teacher. They also did the activity by practicing dialogue.

They (the students) are quite good in giving attention, some of them are not or noisy. But, they do the activity or practice the dialog. The students learned English both in classroom and in the Multimedia Laboratory.

They were more active when they were studying in the Multimedia Laboratory. The students who are active in the Multimedia Laboratory are usually active in class, too. For some students, they are active in the Multimedia Laboratory, but they are not interested in class. Usually, the students are more active in Multimedia Laboratory than in class. They are more active in the Multimedia Laboratory maybe because there is media that is interesting for the students.

The other rersearcher, Putri (2014) found that the teacher talk was the most dominant classroom interaction during the observation. In addition, both teacher $\mathrm{A}$ and $\mathrm{B}$, the content cross was the most dominant characteristics during the observation. The characteristics showed the correlation to the teacher indirect and direct talk that was the teacher spent talking time more in teaching and learning process to ask questions and lecture. From the result, the researcher concluded that the students were not active enough in the classroom interaction.

The students practiced the expression asked by the teacher, even when the teacher didn't ask them. They participated in the class discussion. It might be influenced by the use of the media (such as, computer program and textbook) that was quite interesting for the students. It might also because the number of the students that was not too many in class. They were only 20 students in one meeting. There were enough time and attention given by the teacher to all students.

The use of English for communication in classroom was very rarely. The teacher and the students never spoke in English. They spoke mostly in Indonesian. It was only greetings that were always spoken in English. The students very rarely communicate in English to the teacher and friends. They use Indonesian more often. The teacher uses Indonesian more in explaining the material.

The communication that happened among the students was about asking difficult English expressions and practicing dialogue/activity. When the students had difficulty, they asked their friends first before they asked the teacher. The 
students' book was only the textbook from school. When they had difficulty in understanding it, they would ask their friends or teacher. They didn't have other books/dictionary to learn. The material in class was very limited from the book. There was no development outside of it.

The role of the teacher in classroom was very important in the success of the English interaction. What happened in class was usually influenced by the teacher's role. The class activity was determined most by the teacher. The teacher should be more often speak in English, so that the students become more usual. The teacher's role is as a mediator. S/he explains the topic and practices more. The teacher knows the knowledge, while the students don't. So, the teacher is the mediator. The students who don't understand the knowledge before will understand it later. The teacher should be able to motivate the students to be more active.

From the interview with the students above, it could be seen that actually the students were aware that they had to learn to communicate in English. They had good understanding that in learning English, they needed to learn how to communicate in English. They needed to know how to use English. They knew that they had to practice English. They understood that they had to do some activities or exercises in order that they had good skill in using English for communication.

In some observation (observation 3,4 , and 6), it was found that the teacher made a class discussion. They were talking about a picture, a dialogue, or a class activity. The teacher tried to use English, but, s/he translated after that. The students tried to answer the teacher's questions. Some students answered in short and simple English expressions and some others answered in Indonesian. I try to answer the teacher's questions, if I can. I try to guess the meaning or the answers if there is a question from the teacher.

There had been an effort from the students to be active in class discussion. They tried to guess the answer or the meaning of the teacher's questions. If they knew the meaning or the answers, they would answer. But, if there was an answer from one student, the other students would keep silent.

The interaction found in the classroom was discussed based on who started the interaction and to whom it was addressed. It also discussed about the condition why the interaction happened. To be more focused, there are four categories: (1) Teacher - student interaction, (2) Teacher - students interaction, (3) Student(s) - 
teacher interaction, (4) Student(s) - student(s) interaction

By using these categories, the interaction that found could be seen more clearly. Although, in some cases, it was quite difficult to differentiate an interaction that happened between the students, and the most dominant interaction between teacher and students were direct teacher interaction.

\section{CONCLUSIONS AND SUGGESTIONS}

\section{Conclusion}

From the discussion about the result of the research, some points about the meaning of classroom interaction can be concluded. They are as follows.

Both the teachers and the students were aware and understood that interaction was important in English learning. They also understood that to be able to interact well, they needed to practice. But, the understanding was not supported by what they did in classroom. The teachers did not give much interactive activity in class. It seemed that the teachers did not believe in the students' competence. There was not much chance for the students to interact either to the teachers or to the other students. The students were not active in practicing their English by asking questions or expressing their idea or opinion. The classroom condition did not make the students feel comfortable to interact in English. Feeling lack of vocabulary, afraid of making mistake, having no self confidence, and feeling ashamed were the students' barrier, and the most dominant interaction between teacher and students were direct teacher interaction.

The interaction between the teachers and the students was limited / was based on the activities in the textbook. Reciprocal interaction in the use of English in communication did not happen. However, the use of media, like computer programs and various textbooks, increased the students' motivation to participate in the class activity. The media and the activities gave the students reasons to interact.

\section{Suggestion}

Based on the findings and the conclusion above, there are some suggestions for relevant parties to increase the quality of the English classroom interaction. They are as follows:

1. More communicative classroom activities are needed to be given to the students.

The activities should give more chance for the students to interact either to the 
teacher or to the other students. It helps to increase the students' confidence to interact in English. Activities like role plays, information gaps, small group, or pair work can be included. These activities also maximize the opportunities to practice as more learners speak for more of the time. These activities provide the students with a reason to speak and listen.

2. Various English textbook are needed. Students can enrich their knowledge by studying from various textbook.

3. The teachers and the students, in together, create a classroom situation that makes the students feel comfortable to initiate an interaction using English. The teachers need to be more frequent using English in class. The use of direct translation can be reduced.

The teachers' encouragement to the students' progress is needed to be improved. The encouragement can motivate the students to be more active in learning. Giving lots of praise and giving feedback on task achievement raise the students' confidence.

\section{REFERENCES}

Allwright and Bailey. (2008). Focus on the Language Classroom: An Introduction to Classroom Research for Language Teacher. New York: Cambridge University Press.

Barnes, D., J. Britton and FI. Rosen. (1971). (Rev.ed.) Language the Learner and the School. Harmondsworth: Penguin.

Best, John W and James, V Khan. (1989). Research in Education. Michigan: Prentice Hall

Brown, D. H.(2000). Principles of Language Learning and Teaching. (4th ed.). New York: Longman.

Brown, H. Douglas. (2001). Language Assessment: Principles and Classroom Practices. New York: Addison Wesley Longman.

Brown, H. Douglas. (1994). Teaching by Principles: An Interactive Approach to Language Pedagogy (second edition). London: Longman, Pearson Education

Burns, A. (1999). The Importance of Videotaping in Kindergarten. California: Dobi Production.

Cameron, L. (2001). Teaching Languages to Young Learners. Cambridge: Cambridge University Press. 
Chaudron, C. (1988). Second Language Classrooms: Research on Teaching and Learning. Cambridge: Cambridge University Press.

Cresswell, John W. 1994. Research Design Qualitative and Quantitative Approaches. California: Sage Publication.

Creswell, J. W. (2009). Design Qualitative, Quantitative and Mixed Methods Approaches, Third Ediciton.: Sage Publications.

Dagarin, M. (2004). Classroom Interaction and Communication Strategies in Learning English as a Foreign. Ljubljana : ELOPE

Ellis, R. (1985). Understanding Second Language Acquisition. London: Oxford University Press.

Flanders, N. A. (1970). Intent, action and feedback: A preparation for teaching. Journal of Teacher Education, 14, 251-260.

Harmer, J. (2001). The Practice of English Language Teaching. Third Edition. New York: Pearson Education Limited.

Harmer, Jeremy. (1998). How to Teach English: An Introduction to the Practice of English Language Teaching. Harlow: Longman

Lynch, T. Nudge. (1999). Nudge: Teacher Interventions in Task Based Teacher Talk. ELT journal, (51/4): 3172325.

Malamah Thomas. (1987). A Classroom Interaction. Oxford: Oxford University Press.

Mingzhi. (2005). Enhancing interaction in our EFL classroom. CELEA Journal Vol. 28 No. 2, pp. 56-62

Murtiningrum, Siti. (2009), Classroom Interaction in English Learning. Yogyakarta: Sanata Dharma University

Richards, J., \& Lockhart, C. (1996). Reflective Teaching in Second language Classrooms. Cambridge: Cambridge University Press.

Rivers, W.14. (1987). Interaction as the key to teaching language for communication. In Interactive Language Teaching. Cambridge University Press

Suherdi, D. 2009. Classroom Discourse Analysis: A Systemiotic Approach. Bandung: Celtics.

Zamani E, Azimi SA.2006. E-learning from theory to practice.Authors: Terry Anderson \&. Fathi Elloumi. Tehran: Institute for Educational 